\title{
OPPIMISTUTKIMUKSEN AIKAANSAAMAA
}

\author{
"Oppimisvaikeudet eivät ole yksilön ominaisuuksia, \\ vaan systeemisen tarkastelutavan mukaan ne ovat syntyneet \\ vuorovaikutusjärjestelmän sisällä ja siksi koko järjestelmä \\ on niistä vastuussa. Eikö nyt olisi otollinen aika käynnistää keskustelu \\ kouluoppimisen kehittämisestä lähemmäs luonnollista oppimista, \\ jossa esimerkiksi tavoitteiden asettelu lähtee lapsen tai nuoren \\ omista intresseistä? Vaikka tutkijat luotaavatkin tulevaisuuteen, \\ jäävät ideat mielestäni puolitiehen $\mathrm{mm}$. siksi, \\ että lähtökohta on oppilaita sopeuttava toimintamalli", \\ kirjoittaa Eero Ropo arviossaan.
}

\begin{abstract}
Marja Vauras (toim.) 1993. Oppimisvaikeudet ja opetuksen kehittäminen: Katsaus Turun yliopiston Oppimistutkimuskeskuksen toimintaan ja tutkimukseen. Acta Psychologica Fennica. Soveltavan psykologian monografioita 6. Suomen psykologinen seura. $85 \mathrm{~s}$.
\end{abstract}

Turkulaisten oppimisen tutkijoiden yhteistyön hedelmiä on koottu tiiviiseen yhteenvetoon, jossa tarkastellaan vuosien aikana saatuja tutkimustuloksia ja luodataan myös näkymiä tulevaisuuteen. Oppimistutkimuskeskuksella on syytä tyytyväisyyteen saaduista aikaansaannoksista. Tällaista tutkimusyhteistyötä ei ensinnäkään synnytetä kovin helposti eivätkä tulokset kansainvälisillä foorumeillakaan ole yleensä näin mittavia. Yleisistä kehuista huolimatta on kuitenkin aihetta esittää kriittisiä kysymyksiä, jotka toivottavasti auttavat suuntaamaan tulevaisuuden tutkimustoimintaa oppimisen ja opetuksen alueella.

\section{Lähtökohtana oppijan auttaminen}

Oppimistutkimuskeskus on asettanut tehtäväkseen tarkastella oppimisvaikeuksia samanaikaisesti sisältöalueen kognitiivisena rakentumisena ja yksilön sosioemotionaalisten tulkintojen ja motivoivien hallintapäämäärien kehittymisenä sekä osana yksilön oppimishistoriaa koulun ja kodin muodostamassa sosiaalisessa yhteisössä. Systeemistä näkökulmaa siis korostetaan, mikä lieneekin ainoa oikea lähestymistapa. Kuitenkin systeemisyys tässä tarkoittaa yksilökeskeistä systeemisyyttä, jossa pyritään ymmärtämään ja auttamaan yksilöä ilman, että puututtaisiin systeemin muiden osapuolien toimintaan.

Raporttia lukiessani tämän näkökulman rajoitukset koulun kehittämisen näkökulmasta ovat varsin selvät. Tulevaisuudessa emme voi tyytyä vain hoitamaan oppilaita, vaan meidän on pystyttävä tekemään oppimisvaikeuksista myös pidemmälle meneviä johtopäätöksiä esimerkiksi sen suhteen, millaiseksi haluamme koulun ja kouluopetuksen kehittyvän.

Oppimisvaikeudethan eivät ole yksilön ominaisuuksia, vaan systeemisen tarkastelutavan mukaan ne ovat syntyneet vuorovaikutusjärjestelmän sisällä ja siksi koko järjestelmä on niistä vastuussa. Tätä näkökulmaa tukevaa situationaalisen kognition teoriaa ei 1980luvulla, jolloin oppimistutkimuskeskus perustettiin, ei vielä ollut tai jos olikin sitä ei tunnettu kovinkaan laajasti. 
Pekka Niemi ym. esittelevät lukemisvaikeuksien tutkimustuloksia. Tällä tutkimuksella on selkeitä koulutuspoliittisia ja opetussuunnitelmallisia seurauksia, jos niin halultaan. Esikoulun opetussuunnitelmia laativien olisi syytä paneutua tarkasti tähän jaksoon.

Luvun anti on myös se havainto, ettei koulu tällä hetkellä pysty kovin hyvin korjaamaan oppimisvaikeuksia, vaan tähän tarvitaan yksilöllistä erityisopetusta. Suorastaan huvittavalta optimismilta kuulostaa lause: "Kognitiivinen oppimisen teoria on osoittautunut yllättävän hampaattomaksi, mitä tulee työrauhan ylläpitämiseen ryhmissä" (s. 14). Odotukset oppimisen tutkijoiden suhteen ovat todella kovat, kun tutkijat ovat joutuneet kirjaamaan tämmöisenkin virkkeen raporttiinsa.

Marja Vauras ym. kuvaavat kolmannessa luvussa laaja-alaisten oppimisvaikeuksien olemusta. jo luvun johdannon lukeminen osoittaa ongelman teoreettisen monimutkaisuuden, mutta samalla myös sen intuitiivisen yksinkertaisuuden. Jos lapsi ei opi arvostamaan itseään, jäävät oppimisen taidot puolitiehen. Tämä on tietysti äärimmäisen lyhyesti ilmaistu tässä, mutta raportissa huomattavasti paremmin.

Koulutuksen kehittäjinä meidän olisi kysyttävä, miten voisimme viestiä oppilaille, että he ovat hyviä. jos tämä viesti menee perille, he alkavat uskoa olevansa hyviä ja heistä tulee hyviä. Toisin sanoen oppimisen taitojen oppiminen vaatii niin paljon ponnistelua, ettei siitä voi suoriutua ilman uskoa omiin kykyihin.

Metakognitiivisten taitojen ja strategioiden tutkimus on tärkeää perustutkimusta, josta en kuitenkaan usko olevan hyötyä käytännön opetustyössä olevalle muutoin kuin ehkä sen tiedostamisessa, että suoralla opetuksella ei päästä kovin pysyviin tuloksiin. Taitojen opettaminen irrallaan niiden luonnollisista yhteyksista on monesti vain ajanhaaskausta. Huonosti opitut oppimisen taidot eivät ehkä kerrokaan metakognitiivisten taitojen ongelmista, vaan kouluopetuksen tavoitteiden epäoleellisuudesta suhteessa lapsen tai nuoren maailmaan. jälleen kerran jää mieleen kysymys, eikö nyt olisi otollinen aika käynnistää keskustelu kouluoppimisen kehittämisestä lähemmäs luonnollista oppimista, jossa esimerkiksi tavoitteiden asettelu lähtee lapsen tai nuoren omista intresseistä. Vaikka tutkijat luotaavatkin tulevaisuuteen, jäävät ideat mielestäni puolitiehen mm. siksi, että lähtökohta on oppilaita sopeuttava toimintamalli.

\section{Matemaattisten oppimisvaikeuksien olemuksesta}

Emo Lehtinen ja Riitta Kinnunen tarkastelevat matemaattisten oppimisvaikeuksien olemusta luvussa 4. Tämän luvun sisältö on hyvä katsaus matemaattisten taitojen kehityksen prosesseihin ja ongelmiin. Lukijalle tämä luku näyttäytyy vahvana osaamisena, joka kohdistuu, kuten voi olettaakin, varsin yksityiskohtaisiin matemaattisen osaamisen virheiden ja väärinymmärrysten kuvaukseen. Paikka paikoin huokuu myös huolestuneisuus koulumatematiikan tilasta ja tulevaisuudesta ja muuallakin esiintyneet vaatimukset koulumatematiikan lähentämisestä oppilaiden arkielämään saavat kuvatuista vaikeuksista uutta pontta.

Ratkaisuja ei esitetä ja syy on yksinkertainen: tällä hetkellä niitä ei ole. Kehityksen suunta on kuitenkin selvä eikä se poikkea edellisessä kappaleessa esitetyistä näkökulmista. Kysymys on mitä suurimmassa määrin opetussuunnitelmallinen ja tätä näkökulmaa oppimistutkimuskeskus näyttää myös priorisoivan. Yksilötapausten korjaamiseen ja vaikeuksien analyysiin perustuvat koulutus- ja konsultaatioprojektit näyttävät muodostavan myös tärkeän osan keskuksen tulevaa toimintaa.

\section{Oppikirjatutkimus ja työnohjausprojekti}

Teoksen kaksi viimeistä lukua poikkeavat edellisten tyylistä siinä, että ne esittelevät pikemminkin yksittäisen projektin kuin tutkimussarjan tuloksia. Mirjamaija Mikkilä ja Erkki Olkinuora kuvaavat luvussa 5 oppikirjatutkimusta ja Ari Kaukiainen ja Matti Lappalainen luvussa 6 opettajien työohjausprojektia oppilaiden oppimistaitojen kehittämiseksi.

Molemmat luvut ovat sinällään kiintoisia, joskaan mitään erityistä uutta ne eivät lukijalle tarjoa. Oppikirjojen analyysi pyrkii kuvaamaan olemassa olevien oppikirjojen ominaisuuksia ja onnistuukin tässä varsin monipuolisesti. Raportin lukijan uteliaisuus kohdistuu luonnollisesti esitettyihin parannusehdotuksiin. Tämän kohdan tekijät ovat otsikoineet "Miten oppikirjoista saadaan oppimisen välineitä?". Tekijät 
ehdottavat - 'käsikirjamaisuuden' lisäämistä, tekstityypin muuttamista faktoista erittelevämmäksi, tekstien ja kuvien parempaa integroimista ja työkirjatehtävien tiedollisen aktivointivaikutuksen lisäämistä.

Kaikkia hyviä ehdotuksia, vaikkakin melko yleisiä, on todennäköisesti vaikeita toteuttaa. Voisi esimerkiksi kysyä, onko oppikirjan vaikutus ja merkitys samanlainen kaikille oppilaille. Jos on, esitetyt muutokset saattavat hyvinkin johtaa parempiin oppimistuloksiin. Tekijät itse huomaavat ongelmat todeten esimerkiksi, että oppilaat eivät osaa hyödyntää oppikirjakuvitusta oppimisen apuvälineenä. Kuvia ei katsota ollenkaan tai vain hyvin pintapuolisesti eikä niitä näin osata integroida tekstiin. Tämä on varmaan totta mitä suurimmassa määrin, mutta siinä ei pitäisi tehdä sellaisia päätelmiä, että on opetettava oppilaita katsomaan kuvia paremmin. Tulevaisuudessa oppimisen tutkijoiden on pystyttävä ymmärtämään kouluoppimistakin huomattavasti laajemmassa viitekehyksessä ottaen huomioon oppilaan koko elämänkirjon, esimerkiksi sen, miksi esitetty. kuva (tai oppikirja) ei oppilasta kiinnosta.

Opettajien työnohjauskokeilu on yllättävä 'rönsy' oppimistutkimuskeskuksen tutkimusten sarjassa. Tätä perustellaan kuitenkin hyvin lähtemällä oppilaiden oppimistaitojen kehittämisen tarpeesta ja tiedostaen, ettei näitä taitoja voi kehittää irrallaan opittavista sisällöistä. Projektin tavoitteina oli kehittää opettajien kykyä opettaa oppimistaitoja, kehittää oppilaiden motivaatioperustaa ja oppimisympäristön yleistä laatua. Mielenkiintoisena osatuloksena voisi mainita vaikkapa sen, että jotkut opettajat näyttivät tässä aineistossa aliarvioivan oppilaittensa oppimisen taitoja. Yllättävää, mutta arkikokemusten mukaan liiankin tavallista. Tämä ongelma ei kuitenkaan ole niinkään ko. opettajien ongelma, vaan koulujärjestelmän toimintaperiaatteiden tulosta. Nykyisenlaisessa koulussa oppilaan tarvitsemat oppimistaidot kapeutuvat verrattuna siihen, mihin oppilas luonnollisissa ympäristöissä pystyy ja pystyisi.

Yhteenvetona voisi todeta raportin mielenkiintoiseksi kokonaisuudeksi, josta saa suhteellisen helposti kuvan oppimistutkimuskeskuksen aikaansaannoksista. Yleiskuva on selkeän positiivinen. Tulevaisuutta ajateltaessa lienee edessä kuitenkin kriisejä ja toiminta-ajatuksen kehittämistarvetta, kuten monilla muillakin 1980-luvun organisaatioilla ja yrityksillä.

\section{Eero Ropo}

